\title{
UMA DISCUSSÃO SOBRE O TRATADO DA VARIAÇÃO LINGUÍSTICA NA SALA DE AULA: ANÁLISES E SUGESTÕES
}

\author{
Mariana Santiago Ferreira Freitas ${ }^{1}$, Universidade Federal de Campina Grande \\ (UFCG), \\ E-mail: mariana_una_9@hotmail.com \\ Danilly de Sousa Bezerra², Universidade Federal de Campina Grande (UFCG), \\ E-mail: danillygirl@gmail.com \\ Abdoral Inácio da Silva ${ }^{3}$, Universidade Federal de Campina Grande (UFCG), \\ E-mail: abdoral.silva@bol.com.br
}

\begin{abstract}
RESUMO
Evidencia-se a importância de se trabalhar a variação linguística dentro da sala de aula para sanar os preconceitos ainda existentes sobre o modo de falar das pessoas. Nesse sentido, o objetivo deste trabalho é averiguar se um determinado livro didático do ensino médio preconiza apenas o ensino da norma padrão do português, ou se leva em consideração os níveis de variações linguísticas que vão desde a forma popular até a dita culta. A pesquisa foi realizada por alunas do Curso de Licenciatura em Letras- Língua Portuguesa do Centro de Formação de Professores da Universidade Federal de Campina Grande - CFP/UFCG, juntamente com o professor Abdoral Inácio da Silva. Nasceu da curiosidade em observar a presença ou ausência dos níveis de variações linguísticas possíveis em um livro do ensino médio. No decorrer das observações, constatou-se que o livro traz noções de variações linguísticas. Percebeu-se que os autores se preocuparam em destacar a existência de quatro tipos de variações: sociocultural, situacional, histórica e geográfica. Dessa forma, conclui-se que o advento dos estudos linguísticos contribuiu de forma significativa para evitar certos preconceitos no ambiente escolar, tornando assim o espaço mais harmonioso entre as pessoas, onde todos respeitem os dialetos uns dos outros.
\end{abstract}

PALAVRAS-CHAVE: Variação linguística; Preconceito; Livro didático.

\section{ABSTRACT}

This work evidences the importance of working linguistic variation within classroom to remedy prejudices still existing in the way that people speaking. In that sense, the objective this work is to ascertain whether a certain educational textbook in the middle school advocates only teaching Portuguese Language standard, or takes into consideration levels of linguistic variations ranging from popular form for cultured. The survey was conducted by students of Portuguese Language 
and Literature Course at Centro de Formação de Professores Universidade Federal de Campina Grande - CFP/UFCG. Along with Teacher Abdoral Inácio da Silva. This research was born through curiosity to observe presence or absence of the possible levels linguistic variations in a textbook pertaining a high school. In the course of the observations, it was noted that the textbook brings notions of linguistic variations. It was realized that the authors cared about highlighting the existence of four types variations: sociocultural, situational, historical and geographical. That way, it is concluded that the advent linguistic studies has contributed significantly to avoiding certain prejudices in the school environment, thereby making the space more harmonious among people, where everyone respects each other's dialects.

KEYWORDS: Linguistic variety; Prejudice; Textbook.

\section{INTRODUÇÃO}

Como sabemos é através da linguagem que o ser humano estabelece interação com o mundo que o cerca expondo suas opiniões, desejos, ideologias, etc. Algumas línguas utilizadas pelo homem são formadas, particularmente, por dois eixos: a língua escrita (LE) e a língua falada (LF). Há muito tempo vêm-se realizando estudos sobre a faculdade da linguagem intrínseca ao homem, os mesmos voltados para as regras estruturais das línguas sejam elas: sintáticas, morfológicas ou semânticas.

Por meio de análises linguísticas chegamos à conclusão que a LF é adquirida no domínio familiar e a LE, especialmente, no domínio escolar, assim "a transição do domínio do lar para o domínio da escola é também uma transição de uma cultura predominantemente oral para uma cultura permeada pela escrita" (BORTONIRICARDO, 2004, p. 24). Durante esse processo, podemos observar que muitos professores impõem um olhar muito preconceituoso nas manifestações linguísticas orais das crianças, passando logo nos primeiros anos de letramento a ideia que a escrita é superior fala e findam por não respeitar o modo particular que cada um tem de se expressar, deixando de lado o que conhecemos por variação linguística. De acordo com Marinho e Val (2006), cabe ao professor ensinar aos seus alunos os diversos tipos de variedades linguísticas, e dizer-lhes porque isso acontece, para que assim os discentes possam desde cedo respeitar os dialetos pertencentes a cada falante.

Encontramos em compêndios teóricos, inúmeros estudos sobre a LE, normalmente preocupados com o aspecto estrutural dessa vertente. Ancorando-se em Gurpilhares (2004), podemos ressaltar que esses ensinamentos iniciaram-se nos séculos V a IV a.C. com descrições acerca de uma língua antiga, o Sânscrito. Posteriormente 
chamados de estudos gramaticais com base filosófica, sustentados inúmeras vezes pela lógica, possuindo em seu interior a busca de uma fixidez inerente a língua ao longo dos séculos.

Segundo Gurpilhares (2004), com o intuito de normatizar os estudos da LE nos tempos remotos, os povos helenos passaram a levar em consideração apenas aquilo que estivesse de acordo com os clássicos. Assim, os textos escritos só eram feitos por grandes autores literários da alta sociedade e estes escritos só atingiam à camada mais elevada socialmente, descriminado a mais baixa, já que os textos não chegavam a este público.

Esta visão que afirma que a linguagem "certa" é unicamente a escrita, sobretudo aquela baseada em grandes escritores, ainda está viva no pensamento humano, gerando preconceitos sobre os níveis de manifestações linguísticas dos homens. Nas escolas, por exemplo, a única forma de linguagem que é preconizada é a escrita, esta, por sua vez, apoiada nas gramáticas normativas e sustentadas em um ensino caótico; baseado em frases soltas e descontextualizadas. No entanto, segundos os Parâmetros Curriculares Nacionais PCNs:

Para cumprir bem a função de ensinar a escrita e a língua padrão, a escola precisa livrar-se de vários mitos: o de que existe uma forma correta de falar, o de que a fala de uma região é melhor do que a de outras, o de que a fala correta é a que se aproxima da língua escrita, o de que o brasileiro fala mal o português, o de que o português é uma língua difícil, o de que é preciso consertar a fala do aluno para evitar que ele escreva errado. (BRASIL, 2001, p. 31)

Atualmente é trivial a ideia de que as manifestações sociais e linguísticas estão entrelaçadas quase que de forma inseparável, esse fato vem sendo legitimado ao longo de toda a história da humanidade se caracterizando como a "história de seres organizados em sociedade e detentores de um sistema de comunicação oral, ou seja, de uma língua" (ALKMIM, 2001, p. 21). Baseando-se nos pensamentos de Alkmim (2001), podemos afirmar que a primeira modalidade linguística que temos conhecimento é a língua oral, e que posteriormente a esse fenômeno é que surge em algumas línguas a modalidade escrita. 
Por conseguinte, graças aos estudos linguísticos (sobretudo os da sociolinguística) chegamos à conclusão que tanto a língua falada quanto a escrita fazem parte de um mesmo sistema de regras, em que a segunda é uma espécie de registro da outra. Mas se uma é expansão da outra porque será que as escolas dão mais prioridade a linguagem escrita? Essa forma de elevar uma e desmerecer a outra vem sendo perpetuado desde os estudos gramaticais de base filosófica, em que os estudiosos da época pensavam a língua como um sistema fechado, portanto não possível de variação.

As temáticas das variações linguísticas acertaram em cheio o processo de ensino e aprendizagem, tendo em vista que durante muito tempo vem sendo empregado nas salas de aula a valorização unicamente da LE e o desprezo e abandono da LF. Com o intuito de sanar esse problema, vários pesquisadores da área de língua e ensino passaram a pesquisar sobre o fenômeno com o intuito de criarem implicações pedagógicas que visem o ensino dessas duas modalidades concomitantemente. Pois não é viável que os professores de língua tentem ensinar a escrever apenas por meio da oralidade, já que esta é variável, como também não podem forçar os educandos a falar da forma que se escreve, visto que, conforme Bortoni-Ricardo (2004, p.33) "toda variedade regional ou falar é, antes de tudo, um instrumento indenitário, isto é, um recurso que confere a identidade a um grupo social" assim, é papel do professor respeitar esse aspecto característico de cada ser individualmente.

Dessa maneira, é imprescindível respeitar a forma como cada aluno se expressa, até porque esses níveis de variações linguísticas considerados "erros" pelas gramáticas normativas são apenas uma variação de molde linguístico considerado desvio e são totalmente possíveis, tanto na modalidade oral quanto na escrita. Segundo Bagno (2011), é fundamental desmitificar algumas ideias relacionadas à língua e ensino, já que a forma como o português é ensinado na escola é distinto daquele que usamos no dia a dia. A Gramática mostra-nos as regras, todavia quem movimenta e faz da língua um sistema vivo e versátil somos nós, agentes da comunicação.

Nesse sentido, o presente trabalho pretende averiguar se um livro didático do ensino médio preconiza apenas o ensino da norma padrão do português, ou se leva em consideração os níveis de variações linguísticas permitidas graças as normas de nossa língua, institucionalizadas pelas regras: fonológicas, morfológicas e sintáticas. Além disso, observar determinados pontos referentes a essa temática, como: os tipos de 
variações mencionadas no capítulo analisado, se é levado em consideração o nível de maturidade do aluno, se o conteúdo é tratado de forma adequada e por último se o capítulo aborda com preferência o modo de falar de uma determinada região.

\section{METODOLOGIA}

A pesquisa foi realizada por alunas do Curso de Licenciatura em Letras- Língua Portuguesa do Centro de Formação de Professores da Universidade Federal de Campina Grande - CFP/UFCG, juntamente com o professor Mestrando Abdoral Inácio da Silva. Nasceu da curiosidade em observar a presença ou ausência dos níveis de variações linguísticas possíveis em um livro didático do ensino médio, conhecidas em meio as aulas de língua latina sob a responsabilidade do referido professor.

Em conformidade com Neves et al. (2013), quanto aos procedimentos é do tipo bibliográfica, e de natureza básica, uma vez que foram discutidos dados já existentes. Trata-se de uma pesquisa descritiva, tendo em vista que o assunto tratado já foi explorado por outros autores. De acordo com Gerhardt e Silveira (2009), quanto a abordagem é qualitativa, pois esclarece o porquê das coisas, manifestando o que condiz ser feito.

\section{RESULTADOS E DISCUSSÃO}

Quando observado se o livro traz noções de variações linguísticas, constatou-se que sim, e isto é imprescindível, pois com isso, os discentes saberão lidar com os diferentes modos de falar de cada um, respeitando as diversidades e anulado o preconceito que infelizmente ainda é muito presente em sala de aula. Além disso, entenderão que no nosso país perpetuam-se muitos dialetos e é necessário acatar essas variações. Os próprios autores do livro didático foram muito felizes quando introduziram o capítulo exprimindo os diversos fatores que influenciam nas variações, são eles: a situação de comunicação, a idade, o grupo social que fazem parte, a época, entre outros. Segundo Silva e Carvalho (2013, p. 94), “as escolhas linguísticas do 
falante são feitas de acordo com suas necessidades e, diferentemente do que muitos pensam, não causam a deterioração, o aviltamento da língua”.

Referente à análise dos tipos de variações mencionadas no capítulo, evidenciouse que os autores se preocuparam em destacar a existência de quatro tipos de variações: sociocultural, situacional, histórica e geográfica. Com isso, percebe-se o quão importante é mostrar as circunstancias em que isso pode acontecer. Para manifestar essas ocorrências, têm-se exemplos de cada uma. De acordo com Santana e Neves (2015, p.79), "no Brasil, as variações linguísticas presentes carregam suas riquezas, heranças culturais e representam a identidade do povo brasileiro".

Com relação a adequação ao nível de maturidade do aluno, observou-se que a linguagem é bem acessível, facilitando a compreensão dos mesmos, além de contribuir no momento da aula, pois quando o livro faz uso de uma linguagem muito rebuscada o próprio professor tem dificuldade em repassar os conteúdos, visto que o discente ainda não tem maturidade suficiente para compreender uma linguagem tão "requintada".

Quando verificado se o conteúdo é tratado de forma adequada, certificou-se que sim, uma vez que ao abordá-lo, os autores, mostraram os tipos de contextos e as situações que são admissíveis usar o português visto como popular e o erudito. E também utilizam como arcabouço teórico linguistas bem renomados, como Castilho, para destacar como se dão as variações sociolinguísticas. Segundo Camacho (2011), a variação é um fenômeno que deve ser aceitável, já que o mesmo é pautado pelas próprias regras do sistema linguístico.

Quando averiguado se o capítulo aborda com preferência o modo de falar de uma determinada região em detrimento das demais, percebeu-se que não, já que os autores citaram os tipos de variações linguísticas oriundas da variação geográfica, e fizeram uso de textos para mostrar a diferença nos modos de falar do povo brasileiro que vão desde o sotaque do sertanejo até o das pessoas mais cultas. Conforme as discussões de Alkmim (2001), podemos afirmar que um dos objetos de estudo da sociolinguística é a variação linguística ocasionada por diversos fatores - idade, sexo, escolaridade, região e etc. - no interior dos vários domínios linguísticos.

\section{CONCLUSÂO}


Ao observarmos o corpus aqui analisado, podemos verificar que a forma como os teóricos viam a língua em um passado não tão remoto colocava em holofote a LE, não utilizada em todas as línguas humanas, sendo esta posta em um patamar superior ao da LF. Gerando, dessa maneira, vários preconceitos envoltos no estudo da LF baseado em discussões, muitas vezes, abstratas. Esse tratado com a língua foi perpetuado de forma dogmática em muitas escolas por um longo período de tempo. No entanto, com o advento dos estudos linguísticos, especialmente os estudos da sociolinguística, percebeu-se que a língua falada merecia também seu devido respeito de ser estudada pelos educandos por intermédio de seus mestres.

Foi constatado que no Brasil esse preconceito acerca da LF também era perpetuado na sociedade, principalmente no ambiente escolástico. Porém, com o advento da linguística houve uma mudança significativa, e os PCNs de língua portuguesa passaram a legitimar por meio de documentos oficiais a implantação dos estudos dessa modalidade na sala de aula.

As batalhas travadas entre linguistas e normativos foram vencidas pelos primeiros e o estudo da língua falada ganhou espaço no ambiente escolástico. Dessa forma, os professores passaram a trabalhar tanto a gramática por meio da língua escrita como da língua falada, elencando o estreitamento destas com a sociedade, explicando o porquê que as línguas variam; destacando seus verdadeiros motivos, que como vimos diz respeito: a idade, ao sexo, região, fatores históricos e etc; podendo assim, sanar o preconceito existente entre o linguajar da zona urbana e da zona rural, por exemplo.

A valorização da língua falada ainda não ganhou às proporções desejadas, haja vista que o trabalho com a modalidade escrita é menos complexo. Esse desejo que a escola leve em consideração a modalidade oral da mesma forma como leva a escrita é tão árduo por parte dos teóricos que encontramos atualmente nos livros didáticos discussões com propostas para os estudos linguísticos por meio da oralidade, e sobretudo, acerca dos estudos das variações linguísticas em nosso país, explicando as causas desses fenômenos por meio de uma linguagem acessível de ser transmitida pelo professor aos educandos de acordo com o nível cognitivo de cada ciclo escolar.

Nosso maior objetivo aqui é reafirmamos o quanto o tratado com as variações linguísticas é importante na sala de aula. É imprescindível que os professores de língua portuguesa se conscientizem a respeito deste conteúdo e caso o mesmo não esteja 
incluso nos livros didáticos, cabe ao educador buscar outras fontes como forma de incentivo. Propomos que o docente sonde a variação linguística de nosso país por meio de atividades lúdicas, procurando-a na nossa riquíssima literatura popular, em autores renomados e regionalistas, já que o linguajar de nosso povo está estampado em muitas dessas obras. Assim, efetuando um trabalho profissionalizado e dando aos seus alunos a oportunidade de conhecer as peculiaridades de sua língua materna.

Concluímos nossa jornada de forma satisfatória, tendo em vista que além de almejarmos que nossos objetivos aqui traçados sejam alcançados, acreditamos que mesmo de forma simples, contribuiremos para um tratado da língua de maneira mais concreta e significativa. Além de instruir sobre o assunto tanto professores em formação como discentes já em atuação.

\section{REFERÊNCIAS BIBLIOGRÁFICAS}

ALKMIM, T. M. Sociolinguística In: Mussalin, F. et al: Introdução a linguística: domínios e fronteiras. São Paulo: Cortez, p. 21-43, 2001.

BAGNO, M. Preconceito linguístico: o que é, como se faz. $4^{\mathrm{a}}$ ed. São Paulo: Edições Loyola, 2000. 145 p.

BORTONI - RICARDO. S. M. Educação em língua materna: a sociolinguística na sala de aula. São Paulo, Parábola, 2004. 155p.

BRASIL. M. da E. S de E. F. Parâmetros Curriculares Nacionais: língua portuguesa $\left(1^{\circ}\right.$ e $4^{\circ}$ ciclos do ensino fundamental). v. 2. Brasília: MEC, 2001. 144p.

CAMACHO, R. G. Norma culta e variedades linguísticas. São José do Rio Preto: Unesp, 2011, p. 34-49.

GERHARDT, T. E.; SILVEIRA, D. T. Métodos de pesquisa. Rio Grande do Sul: UFRGS, 2009. 114p.

GURPILHARES, M. S. S. As bases filosóficas da gramática normativa: uma abordagem histórica. Janus, lorena, ano 1, $2^{\circ}$ semestre de 2004.

MARINHO, J. H. C.; VAL, M. da G. C. Variação linguística e ensino. Belo Horizonte: Ceale, 2006. 60 p.

NEVES, L. M. B. et al. Tutorial de Pesquisa Bibliográfica. Pesquisa Científica, Paraná, p. 01-48, 2013. 
SANTANA, J. O. de; NEVES, M. do B. P. F. das. As variações linguísticas e suas implicações na prática docente.

Disponível

em:

<http://www.ipv.pt/millenium/Millenium48/6.pdf>. Acesso em: 14 agosto. 2017.

SILVA, F. M da.; CARVALHO, M. A. A. A variação linguística em livros didáticos de língua portuguesa. v. 3, n. 9, p. 86-106, 2013. 